\title{
The Muek-lek Women's Dairy Project in Thailand
}

Aruna Rao

Follow this and additional works at: https://knowledgecommons.popcouncil.org/departments_sbsr-pgy

Part of the Demography, Population, and Ecology Commons, Family, Life Course, and Society Commons, Gender and Sexuality Commons, International Public Health Commons, and the Regional Economics Commons How does access to this work benefit you? Let us know!

\section{Recommended Citation}

Rao, Aruna. 1990. "The Muek-lek Women's Dairy Project in Thailand," SEEDS no. 12. New York: Population Council. 

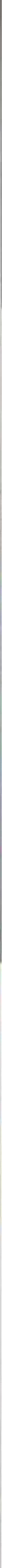
SEEDS is a pamphlet series developed to meet requests from all over the worid for information about innovative and practical program ideas developed by and for low income women. The pamphlets are designed as a means to share information and spark new projects based on the positive experiences of women who are working to help themselves and other women improve their economic status. The projects described in this and other issues of SEEDS have been selected because they provide women with a cash income, involve women in decision-making as well as earning, are based on sound economic criteria, and are working successfully to overcome obstacles commonly encountered. The reports are not meant to be prescriptive, since every development effort will face somewhat different problems and resources. Rather, they have been written to describe the history of an idea and its implementation in the hope that the lessons learned can be useful in a variety of settings. They are also being written to bring to the attention of those in decision-making positions the fact that income generating projects for and by women are viable and have important roles to play in development.

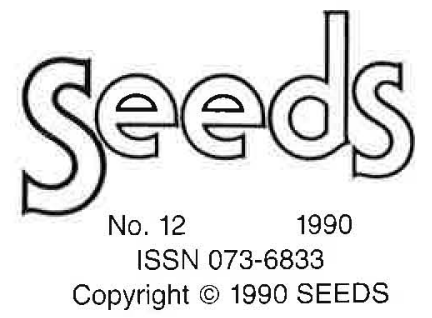

The Population Council provides project direction and administrative supporl for SEEDS. Editorial policy is set by the SEEDS Steering Committee: Judith Bruce (The Population Council), Marty Chen (Harvard Instilute lor international Development), Margaret Clark (The Ford Foundation), Cecilia Lotse (UNICEF), Katharine McKee (Center for Community Self-Help), Anne Walker (International Women's Tribune Center), Mildred Warner (Cornell University), and Ann Leonard (Editor).

Publication of SEEDS is made possible by supporl of the Ford Foundation, the Government of the Netherlands, the Population Council and UNICEF.

Statements made and views expressed in this publication are solely the responsibility of the author and not of any organization providing support for SEEDS. 


\title{
The Muek-Lek Women's Dairy Project in Thailand
}

\author{
Story by Aruna Rao
}

\section{Introduction}

This issue of SEEDS describes a project that was started in 1985 to encourage the growth of a new agricultural sector, dairy farming, in Thailand. While the major aim of the project was to increase incomes of rural families in the Muek-Lek Land Reform Area in Saraburi Province, Central Thailand, it also sought to integrate women into dairying activities, and offer these women, whether married or single, access to credit.

It is unusual for women to have an opportunity to participate in the formation of a new and highly profitable agricultural industry. The Muek-Lek Dairy Project is unique in that it has channeled government resources and secured commercial bank financing to make women the key participants in a relatively new and growing agricultural sector in Thailand. Primarily the initiative of two prominent Thai women, a banker and the director of a national NGO, with the support of an international women's banking organization, the project has had a major impact on increasing women's income, status, and access to government and private sector resources. 


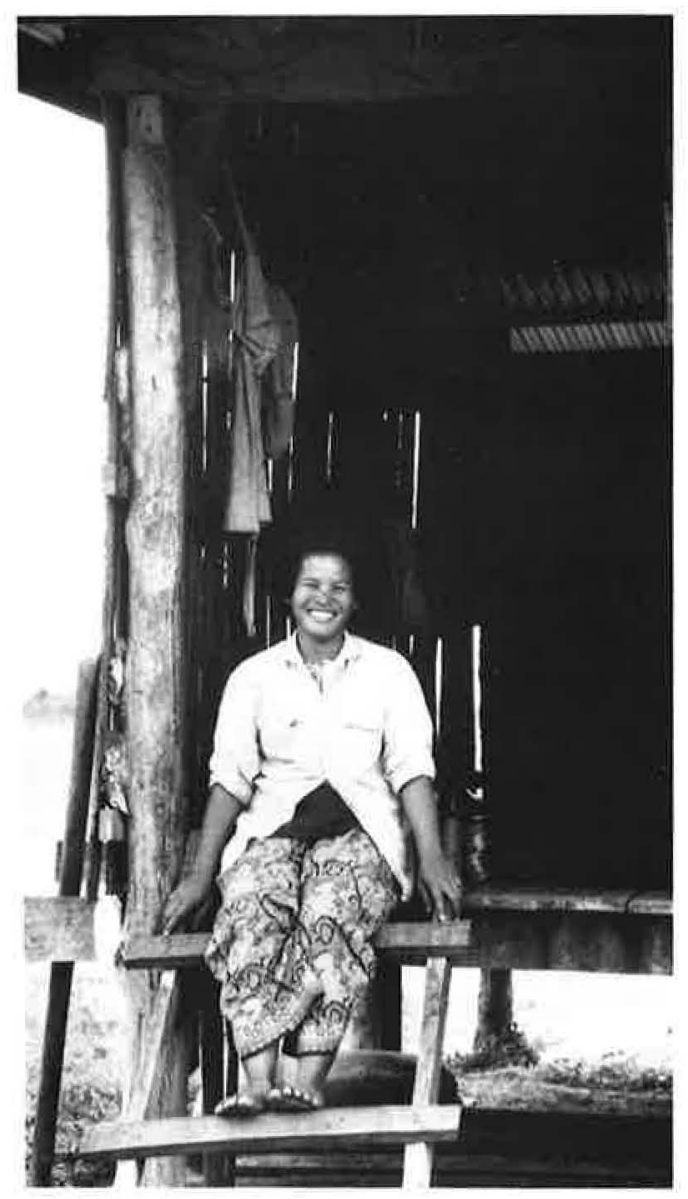

Barefoot and sarong clad, Somchit walks quickly across her small, dry plot of land toward the cattle shed where her seventeen year-old son is guiding cows into their stalls. It is 4:00 p.m.- -afternoon milking time. It takes Somchit twenty minutes to milk one cow; she owns twelve all together. Four years ago, with a 158,000 bhat (U.S. \$6,320) loan from the Bangkok Bank, under a program sponsored by the Friends of Women's World Banking in Thailand, in collaboration with a number of government agencies and national nongovernmental organizations, Somchit bought four dairy cows imported from New Zealand. Before she started dairy farming, she planted corn and earned less than 1,000 bhat $(\$ 40)$ a month. Now she nets over three times that amount.

\section{Women in Thailand}

Women comprise close to half the population of Thailand and about 67 percent are active in the labor market. The majority of Thai women live in rural areas and are employed in agriculture, many as unpaid family labor. However, over the last thirty years the percentage of women in agriculture has declined from 87 to 61 percent as women have moved into commerce, manufacturing and services. In all industries women are concentrated in the lowest income brackets. Although female literacy is high (84 percent), political participation at the local and national levels is not significant and women still do not enjoy legal equality with men in a number of spheres.

\section{History of the Dairy Industry}

Milk consumption is not a tradition in Thailand. Until thirty years ago, cattle were raised primarily as work animals, and also for beef and manure. The earliest dairying activities were started in the 1950 s by Indian settlers around Ayutthaya, the ancient capital of Thailand, located about 80 kilometers north of Bangkok. The fresh milk they produced was sold to consumers in Bangkok. Today dairying continues to be focused primarily in the Central Zone because of its rich agricultural land and availability of cattle feed for most of the year.

Following the Second World War, the Government of Thailand established a milk authority to promote milk production and consumption. However, increasing imports of milk and milk products, which were lower in price and of better quality, undermined local production. Beginning in the early 1960s, the milk processing industry began to expand when the Danish and German governments assisted in setting up model dairy farms in Muek-Lek. By 1972, there were eight milk processing factories producing pasteurized and recombined milk. A dairy farming promotion organization was started under government sponsorship to support research on exotic breeds, provide training, and encourage processing and marketing. Most of the support was targeted to large farms in Saraburi province. Between 1976 and 1982, the demand for milk 
grew by 25 percent per year as incomes (particularly of urban dwellers) improved and more people acquired a taste for milk.

The number of dairy farmers in Thailand has increased from 114 farmers with 3450 cows in 1962, to 4000 farmers with about 24,000 cows in 1986. Imported Holstein-Freisian/Sahival cows have become the norm for the industry due to their high yields and adaptability to conditions in Thailand. Today milk processing remains highly concentrated, with five private sector processing companies responsible for 90 percent of the country's local dairy production -which still meets only 20 percent of demand. In 1988, annual imports of milk and milk products still amounted to about 2,500 million bhat (U.S. $\$ 100$ million), thus indicating a significant opportunity for expanding local production.

As a profitable and rapidly growing sector, dairying presented a unique opportunity to increase women's incomes. The efforts of the consortium of banks, government agencies, and NGOs in the Muek-Lek Dairy Project have enabled 82 poor families to purchase 500 imported cows, making women significant players in the emerging dairy industry.

\section{Muek-Lek: \\ The Setting and the People}

Muek-Lek is located in the province of Saraburi, about $250 \mathrm{~km}$. northwest of Bangkok. Thailand's small but growing dairy industry is concentrated in Saraburi province. However, most poor farmers in the region continue to depend on low return crops such as maize for family income. Most families in Muek-Lek were originally squatters who moved into the area to clear government forest land for cultivation. Squatters and landless laborers in Muek-Lek were granted user rights to the land through the government land reform program of 1979 . While some families managed to register neighboring plots under the names of different family members, thereby retaining relatively large landholdings, the mean size of farms within the land reform area is 30 rai, or eight hectares.

Prior to joining the dairy project, seventy percent of all households in Muek-Lek earned less than 10,000 bhat $(\$ 400)$ per year; thirty-five percent earned less than 6,000 bhat $(\$ 240)$ annually - figures that are substantially lower than for other parts of Thailand. The annual expenses of most households exceeded or just equalled their

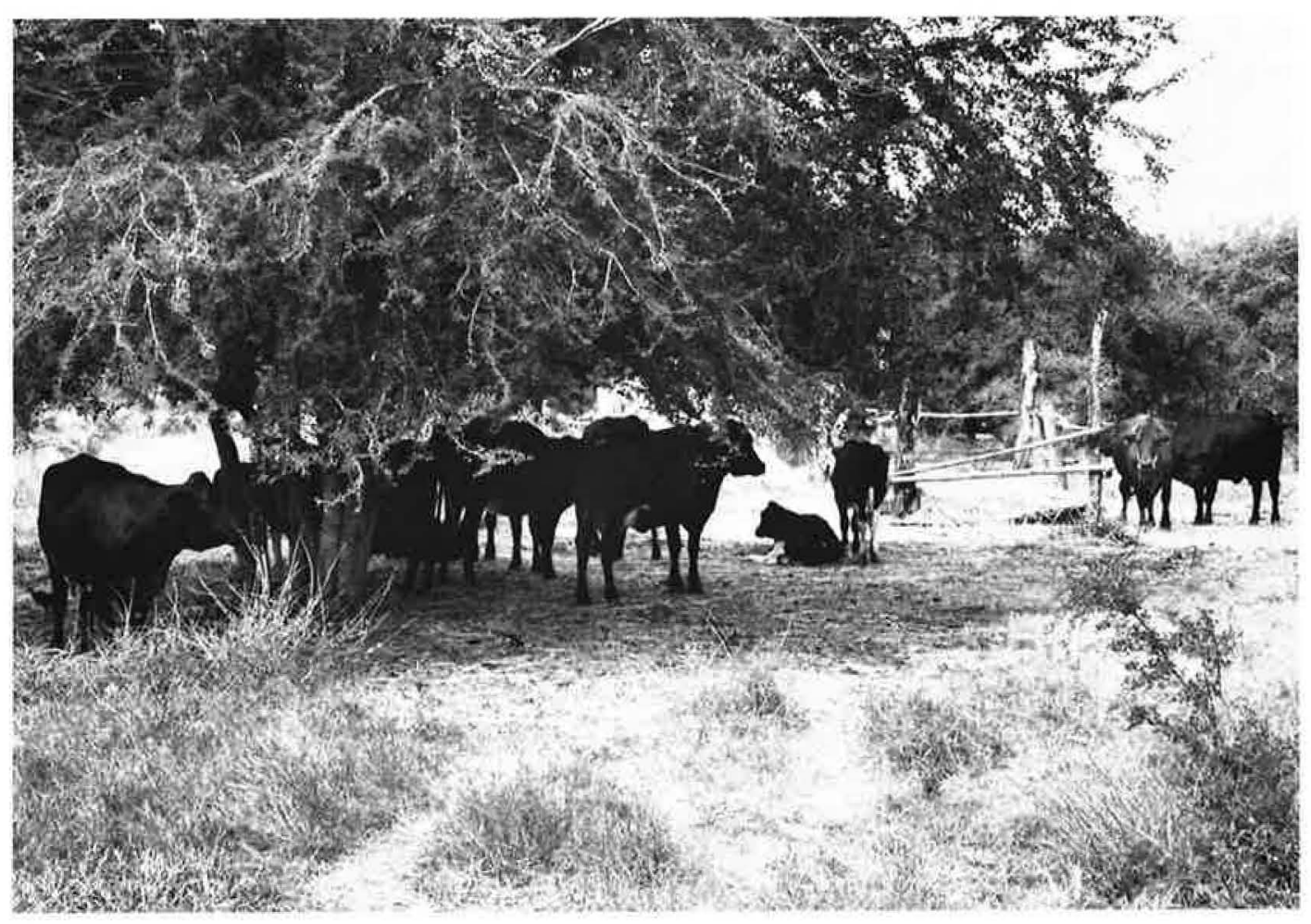


income, and many were borrowing from local merchants at an interest rate of twenty percent. This money was advanced against crops during the four-month period between planting and harvesting. Some male farmers were able to take out loans averaging 5,000 bhat ( $\$ 200$ ) from the local agricultural cooperative, but this credit was not available to women farmers.

Saraburi has a tropical, savanna climate with three seasons: a rainy season from May to October; a cool season from November to February; and a pre-monsoon hot season from February to April. Temperatures range form a high of 32 degrees celsius in April to 16 in December. Only about twenty-one percent of the land is irrigated; most of the annual rainfall comes between May and October. The three consecutive years prior to 1985, when the dairy project started in Muek-Lek, were years of drought.

The lowland areas, with poorly drained clay soils, are planted in rice. Maize, sorghum, mung and soya beans are cultivated in the hilly regions. In the Muek-Lek area the majority of farmers plant maize as their main crop. Agricultural labor is seasonal and often shared between women and men. In late March and early April men are responsible for land preparation for the first crop. Tractors are hired for plowing and oxen are used for furrowing. Planting is done in April, mostly by women, and weeding is carried out three or four weeks later by both women and men. Generally, Muek-Lek farmers do not use chemical fertilizers or pesticides. Harvesting, which is done in July, is also a joint female-male activity. Land preparation for a second crop immediately follows harvesting of the first. The second crop generally produces lower yields than the first due to drier weather. Farmers sell their maize directly to local merchants. Despite the ability to plant a second crop, seasonal underemployment is still a problem for both men and women in Muek-Lek.

Planting corn doesn't yield a good income," says Lek. "It also means money only twice a year, at the end of each cropping season." "Before we had barely enough to

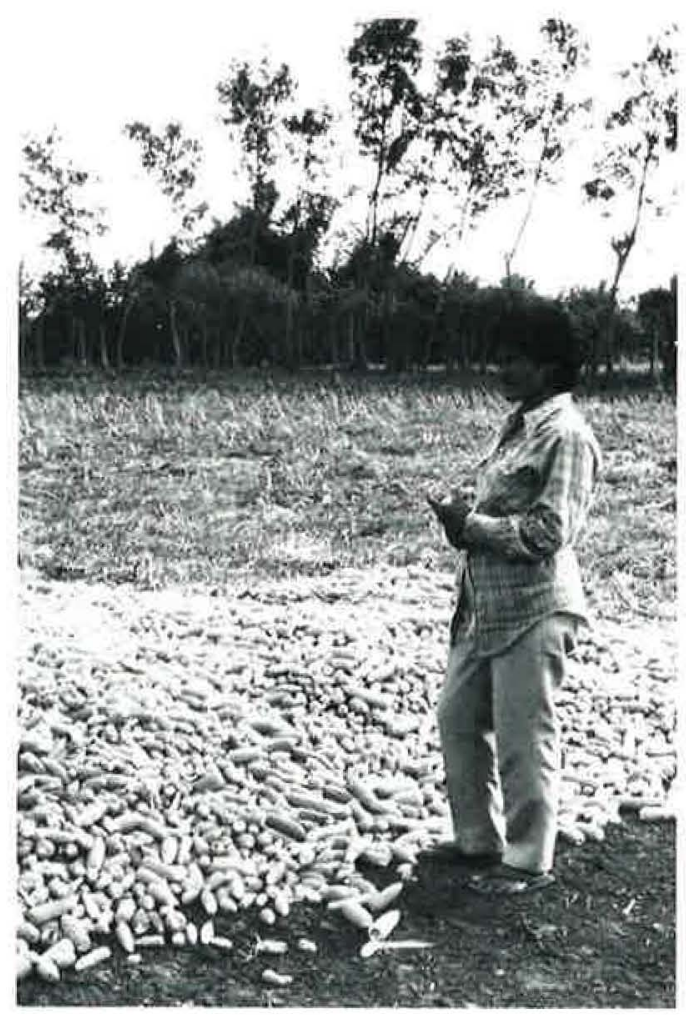

get by; now we have a little extra," adds Lamoon. Both agree that the best thing about the dairy project is that it increased income and spreads it throughout the year.

\section{The Women's Dairy Project}

In 1984, the Thai Institute of Science and Technical Research conducted a study as part of a large rural development project covering a number of sites around the country, including Saraburi. The aim was to identify ways to improve the productivity and incomes of local farmers by focusing on cash crops such as cotton and animal feed, or dairying. Dr. Malee Suwana-adth was an advisor to the Institute at the time. She is the Executive Director of the SVITA Foundation, a private, non-profit organization that promotes small enterprise development in Thailand, particularly among women. Dr. Malee accompanied the research team to Saraburi to explore opportunities for small scale enterprise development. 
The team, accompanied by the MuekLek land reform officer, Khun Kamthorn, visited a series of development sites including an ongoing Thai government/Danish dairy project. This project was experiencing a number of difficulties, including low yields from crossbred cows, and lack of local infrastructure, such as all-weather roads to connect farms with the milk processing plant: (located $30 \mathrm{~km}$. away). Over several months the team, along with the land reform officer, examined the feasibility of different incomeearning activities, taking into account the farmers access to land and capital, their technical know-how, and market demand. Demonstration plots of new crop varieties and practices were planted for farmers to observe. When the study was completed, the team discussed their findings and ideas with local villagers. These villagers then continued to meet as an informal working group to further discuss the various options the team had presented to them. At first the working group included only one woman. Later, with SVITA's encouragement, more and more women joined in the deliberations. Of all the possibilities for augmenting income, the villagers chose to begin dairy farming despite the difficulties faced by other dairy projects in their region. Dairy farming best met their needs because it would provide a steady stream of income throughout the year and help fill their need for employment during slack agricultural periods. They were concerned, however, about the low milk production of local, crossbred cows.

Soon afterwards, Dr. Malee and an associate returned to carry out a feasibility study to determine the minimum amount of assistance that would be necessary to make dairying profitable for each family. They also visited several small dairy projects sponsored by other NGOs in Thailand. Their findings indicated that profitability would require the purchase of imported cows, which yield higher quantities of milk than local or locally crossbred varieties. But neither SVITA nor the provincial administration could provide the necessary funding, and attempts by the land reform officer to secure loans from the nationalized Bank for Agriculture and Cooperatives and the Bangkok Bank were unsuccessful.

\section{Project Financing}

As luck would have it, it was only a short time afterwards that a prominent woman banker, Chinda Charungcharoenvej, Senior Vice President of the Bangkok Bank, called Dr. Malee to ask if SVITA would be interested in starting a dairy project. Ms. Charungcharoenvej, it turned out, was handling transactions for the Ministry of Agriculture to import dairy cows. Dr. Malee told her about the Muek-Lek project idea and explained the problems of raising investment capital. Putting their heads together, the two women came up with a financing scheme using the services of Women's World Banking, an international organization committed to improving women's access to credit and financial services through loan guarantees to in-country lending institutions which make loans to women. Ms. Charungcharoenvej had been encouraged to develop a program for delivery of credit for women's enterprises in Thailand, and this seemed like it might be the perfect opportunity to get started.

The two women received a commitment of five million bhat $(\$ 200,000)$ over a threeyear period from Women's World Banking. Of this amount, 1.7 million bhat $(\$ 66,667)$ was immediately deposited with the Bangkok

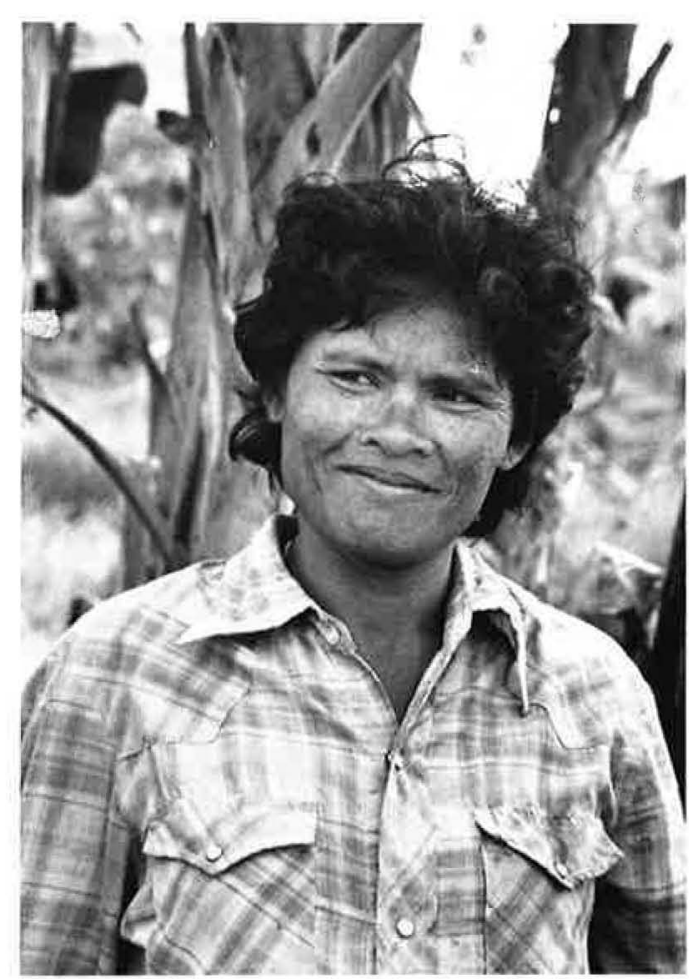




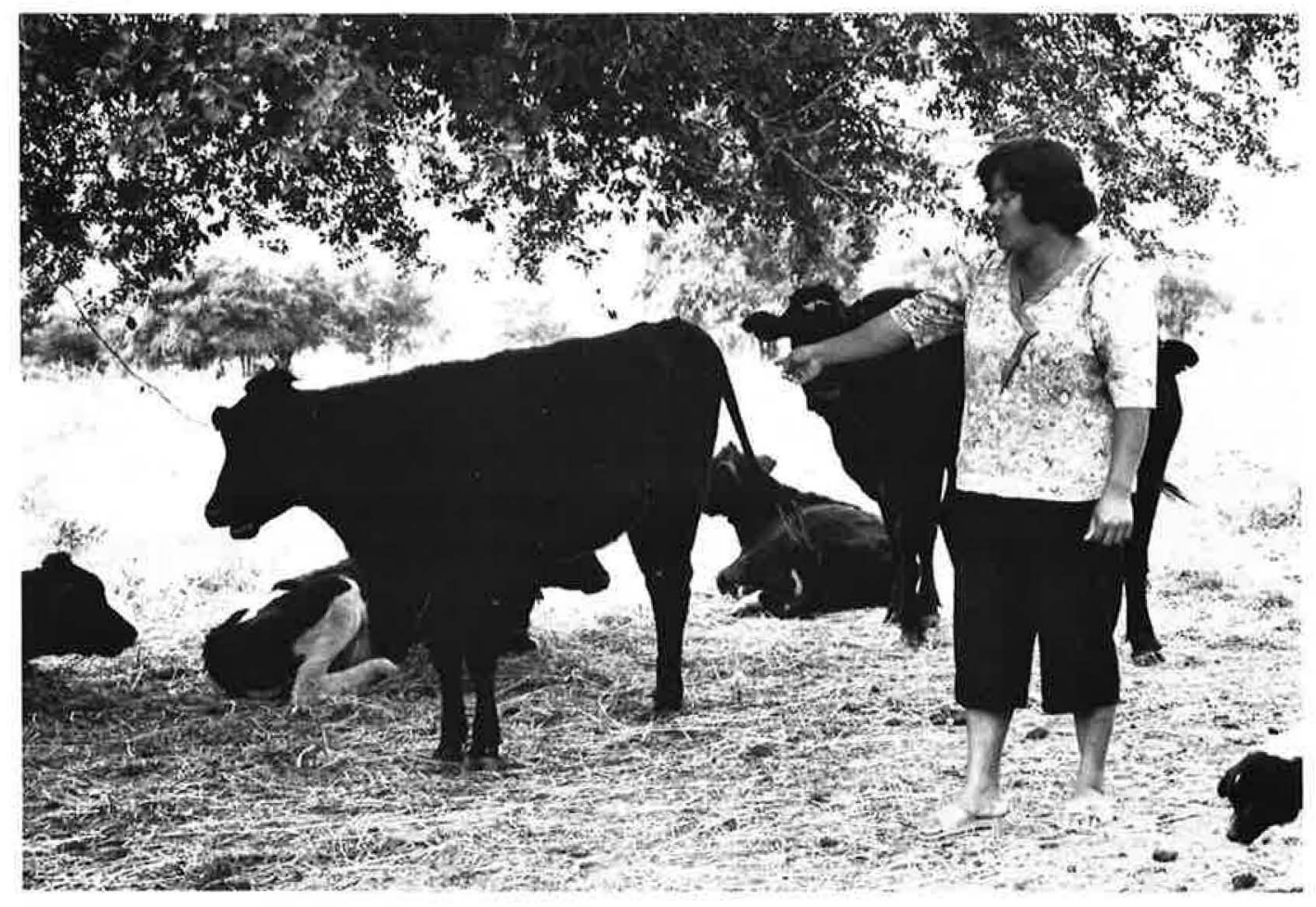

Bank to provide a 50 percent guarantee of the principal needed to start the project. SVITA joined two other Thai NGOs to form an affiliate, Friends of Women's World Banking in Thailand, which deposited 750,000 bhat $(\$ 30,000)$ in the Bangkok Bank as the local share (25 percent) of the guarantee funds for credit to women's economic enterprises. As a result of these guarantees, the bank bore risk on only 25 percent of the principal investment.

At first the Bangkok Bank was very reluctant to get involved in this new and seemingly high-risk area, especially since a previous dairy project it had funded had failed. But the Bank was under pressure to meet its legally stipulated mandate of providing a minimum of eleven to thirteen percent of its total lending portfolio as rural credit. And now the Muek-Lek project had three things going for it: (1) with the loan guarantee, the Bank had substantially reduced its risk; (2) its managers were encouraged by the fact that SVITA would be continuously present to organize, supervise, and monitor the dairy loans and other project activities; and (3) a senior bank staff member would be personally associated with the project. So the Bank conducted its own feasibility study and finally agreed to match the Friends of
Women's World Banking in Thailand deposit with an equivalent amount of its own and to make loans to those women recommended by the cooperating NGOs at a rate of two bhat for every one bhat deposited, as guarantee, in the bank.

\section{Project Design}

To get the project started, the land reform officer and SVITA organized meetings with the villagers to discuss the operational details of starting the dairy project. From the outset, women were expected to play a major role in the project, although all family members would share in the care and milking of the cows. This was a logical decision since women do not migrate for wage work as men do and the activities involved in dairy farming are carried out close to home. Since women already held primary responsibility for family financial management, SVITA stipulated that the principal borrower be the woman, with the male as cosigner, thus reversing the pattern common in Thailand.

Although in most households in MuekLek it is the woman's responsibility to manage household finances, women traditionally 
have not been members of agricultural cooperatives and thus, not eligible to receive such loans. Under land reform, the MuekLek farmers, both male and female, do not hold title to their land; thus, they cannot meet the collateral requirements of the larger commercial or nationalized banks. Even if a woman farmer could meet the loan requirements, however, she would be unlikely to be given credit because of the "head of household" criterion which traditionally means only men are eligible.

The project designers felt strongly that women should be the loan recipients because they would be providing the majority of the labor to the dairy enterprise. In addition, much empirical evidence exists in Thailand to demonstrate that women have better repayment rates than men.

"Women look after money better than men do," says Niphaporn, who bought six dairy cows with her dairy loan. "Men will go out and drink and forget what the loan was for."
By making them the principal borrowers, the project hoped to extend women's financial management skills to activities outside the household and make them feel primarily responsible for repayment of the loan. It also was hoped that this arrangement would give women greater say in family decisions concerning the dairy project. (For additional information on women's experiences with credit, see SEEDS issues Nos. 3, 6, \& 11).

As designed, the project comprised six components, divided into two general categories: 1) credit-dairy loans; and 2) risk management-insurance, training, veterinary services, a feed mill cooperative, and a mechanism for milk collection.

\section{Credit}

Credit is often seen as the principal constraint facing many women's enterprises. While access to financing was critical to this project, it represents only one of many constraints which had to be addressed in order to achieve success. SVITA provided the link between the village working group and the bankers in carrying out negotiations on project financing. When the two groups

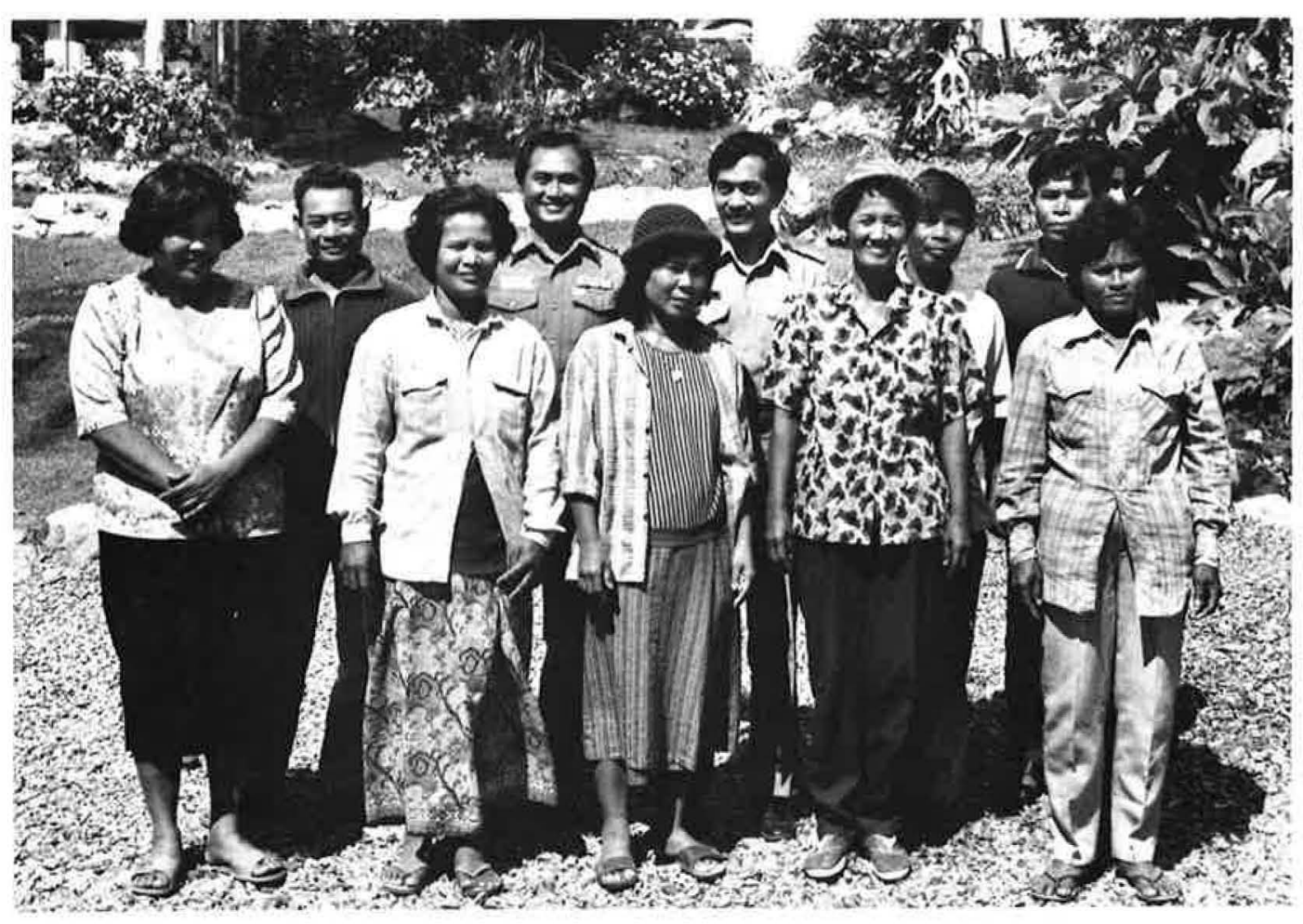


reached an agreement, the land reform officer informed SVITA of their decisions. SVITA was then asked to arrange for the importation of pregnant dairy cows from New Zealand which had been shown to be adaptable to Thai conditions and to yield twice as much milk as local breeds. According to government regulations, a minimum of five hundred cows had to be imported in any one consignment, and each cow cost 25,000 bhat $(\$ 1,000)$. The Bank, in turn, stipulated that a minimum of four cows was necessary per family in order to insure adequate earnings to repay the loan.

Many families wanted to participate and 85 in the area applied for loans. Of these, some owned considerably more land and were better off financially than others but, in the end, the Bangkok Bank approved 82 of the loan applications. The project required the land-cattle ratio noted in the chart. ${ }^{*}$ The differing loan amounts also included other start-up costs such as the cost of electrical fencing, construction of barns and water wells, milking machines (for some farmers), cattle insurance and a mandatory two-month quarantine of the cows at the government dairy promotion organization at Muek-Lek.

The annual interest rate on the loans was thirteen percent, one point lower than the commercial rate. Repayment was scheduled over an eight-year period with a one year grace period. Subsequent monthly payments of principal plus interest were restricted to no more than 30 percent of each family's monthly income. To receive a loan, each borrower had to open an account at the Bangkok Bank. Realizing that it would be impossible for the women to travel 50 $\mathrm{km}$. to the nearest branch of the bank to make their monthly payments, arrangements were made by SVITA to have the payments made for them by the Thai/Danish milk processing plant that would be buying the milk from farmers. The plant keeps a separate account for each farmer, deducting the amount owed the Bank from what is due the farmer for milk purchased at the end of each month.

\section{Risk Management}

While dairying offers the opportunity for increased incomes, it carries substantial risks. The success of this project rests on its recognition of the inherent risks and its effective handling of risk with regard to loan repayment, animal health, women's technical expertise, access to inputs, and access to markets for milk. Had any of these aspects been overlooked, the project might have failed as did earlier dairy projects in the same province.

\section{Insurance}

To protect the investment of the Bangkok Bank and the individual borrowers, Ms. Charungcharoenvej was able to arrange with the Bangkok Insurance Company for cattle insurance that would cover 75 percent of the per head cost in case of loss. Up until this time, no livestock insurance had been available in Thailand. The insurance premium amounted to 1,100 bhat per head per year. Having the insurance has proved invaluable, especially during the first year of the project when 25 cows died of hoof-and-mouth disease resulting from poor livestock management during quarantine. This meant that the affected families could buy another cow.

\begin{tabular}{lll}
\hline A woman holding & Could buy & With a loan of \\
$10-20$ rai $(2.5-5 \mathrm{Ha})^{1}$ & 4 cows & 158,000 bhat $(\$ 6,320)$ \\
$21-30$ rai $(5-8 \mathrm{Ha})$ & up to 5 cows & 193,000 bhat $(\$ 7,720)$ \\
$31-50$ rai $(8-12 \mathrm{Ha})$ & up to 6 cows & 229,000 bhat $(\$ 9,160)$ \\
\hline
\end{tabular}

${ }^{1}$ Eight rai is the average land holding in the land reform area. 


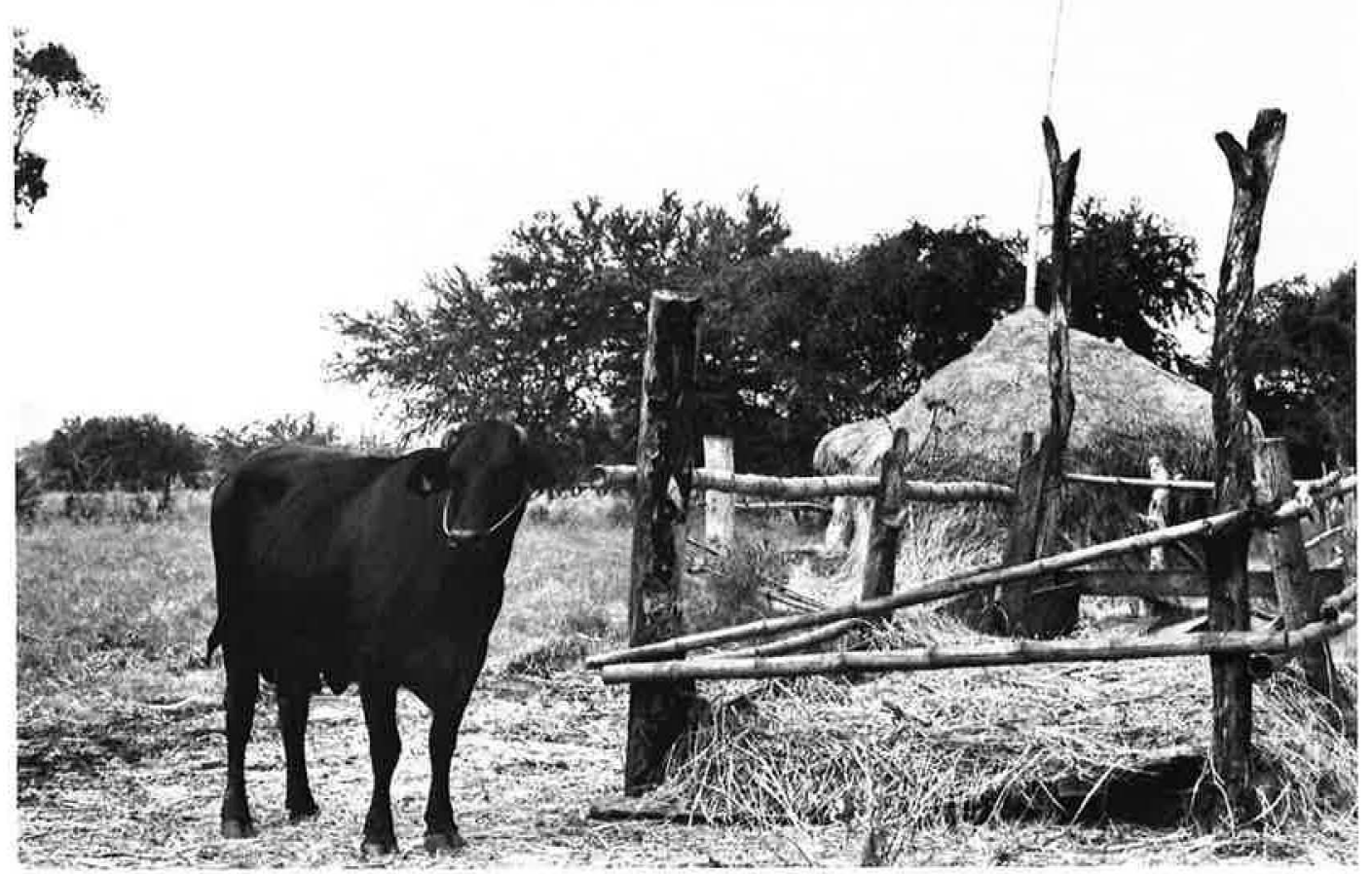

\section{Training}

Training courses in animal husbandry are regularly held by the government sponsored dairy promotion organization in MuekLek. With the assistance of the provincial governor, SVITA persuaded the organization to host a special training course for the farmers participating in the dairy project during a slack agricultural period. One member of each family attended, and 70 percent of the participants were women. All the participants stayed at the training facility for the duration of the course and the provincial administration covered the cost.

\section{Veterinary Services}

The provincial veterinary office at Saraburi regularly provides services to farmers free of charge. For the first year of the project, SVITA paid the provincial veterinarians to visit the farms of individual project families on weekends, when they would normally be off work. This enabled the women to learn how to treat many common problems on their own. Now veterinary services are available on demand, within 24 hours of receiving the request, from the provincial office and from the dairy promotion organization.
The one service farmers continue to pay for is artificial insemination which costs between $150-300$ bhat (\$6-\$12) depending on the breed. While it often requires several attempts before a cow is successfully impregnated, the investment is worthwhile. Farmers can sell a male calf for 200 bhat (\$8) and a female calf for 3000 bhat $(\$ 120)$.

\section{The Feed Mill Cooperative}

To consistently yield large quantities of milk, the New Zealand cows require enriched feed which was not readily available in Muek-Lek. To produce such feed, the Muek-Lek farmers set up a feedmill with a 200,000 bhat $(\$ 8,000)$ grant from the provincial government for construction and the purchase of equipment, and a 100,000 bhat $(\$ 4,000)$ loan from SVITA's Business Development Fund to set up the feedmill operations and for the down payment on a truck.

All the project participants automatically became members of the feedmill cooperative. The farmers elected a committee of ten (made up of members of the original village working group) to oversee general management, quality control, and money collection. From the beginning, the feedmill operations were entirely in the hands of the villagers. 
Initially SVITA provided one of its own staff to help with the accounts. This person was later hired by the feedmill to check the books, first every three months and later at increasing intervals. The cooperative also hired a manager to handle day-to-day operations. During the first year, the cooperative ran into problems: money was being skimmed off and diverted elsewhere. In an effort to revamp, the committee fired the manager and replaced him with a woman who has set the cooperative on a sound footing. The new manager oversees a staff of three: an assistant and two hired hands who grind and mix the feed.

In order to spread the benefits of the dairy project to a wider segment of the local population, the feedmill buys certain feed grains, such as corn, on a preferential basis from local farmers who do not own cattle. Ingredients such as bran and coconut palm powder, which are not produced locally, are purchased nearby.

The dairy farmers buy their feed on credit twice a month. In 1987, after paying back the SVITA Ioan, the feedmill collected 500 bhat from each member to replenish the revolving loan fund. In its second year of operation, the mill started paying a dividend to its members. Its net profit averages between 10,000 and 15,000 bhat ( $\$ 400-600)$ per year. Thus far, each member family is getting back a dividend of a few hundred bhat each year.

\section{Collecting the Milk}

An agreement was made with the Thai/ Danish milk processing plant to purchase milk from the Muek-Lek dairy farmers at the standard rate of 6.50 bhat per kilogram. But transporting the milk was a problem for the farmers; some lived $50 \mathrm{~km}$. away from the processing plant and few had access to transportation. Those who owned trucks saw this as an opportunity to make some money and offered to transport the milk at a very high price. Here SVITA, in its role as project advisor, was able to help the farmers weigh the alternatives, including the possibility of using the feedmill truck to transport the milk themselves or taking out a loan to buy a new truck. Seeing that they might end up out of a job, the local truck owners decided to lower their price. Ultimately they were hired by the farmers to transport the milk at a fair price.

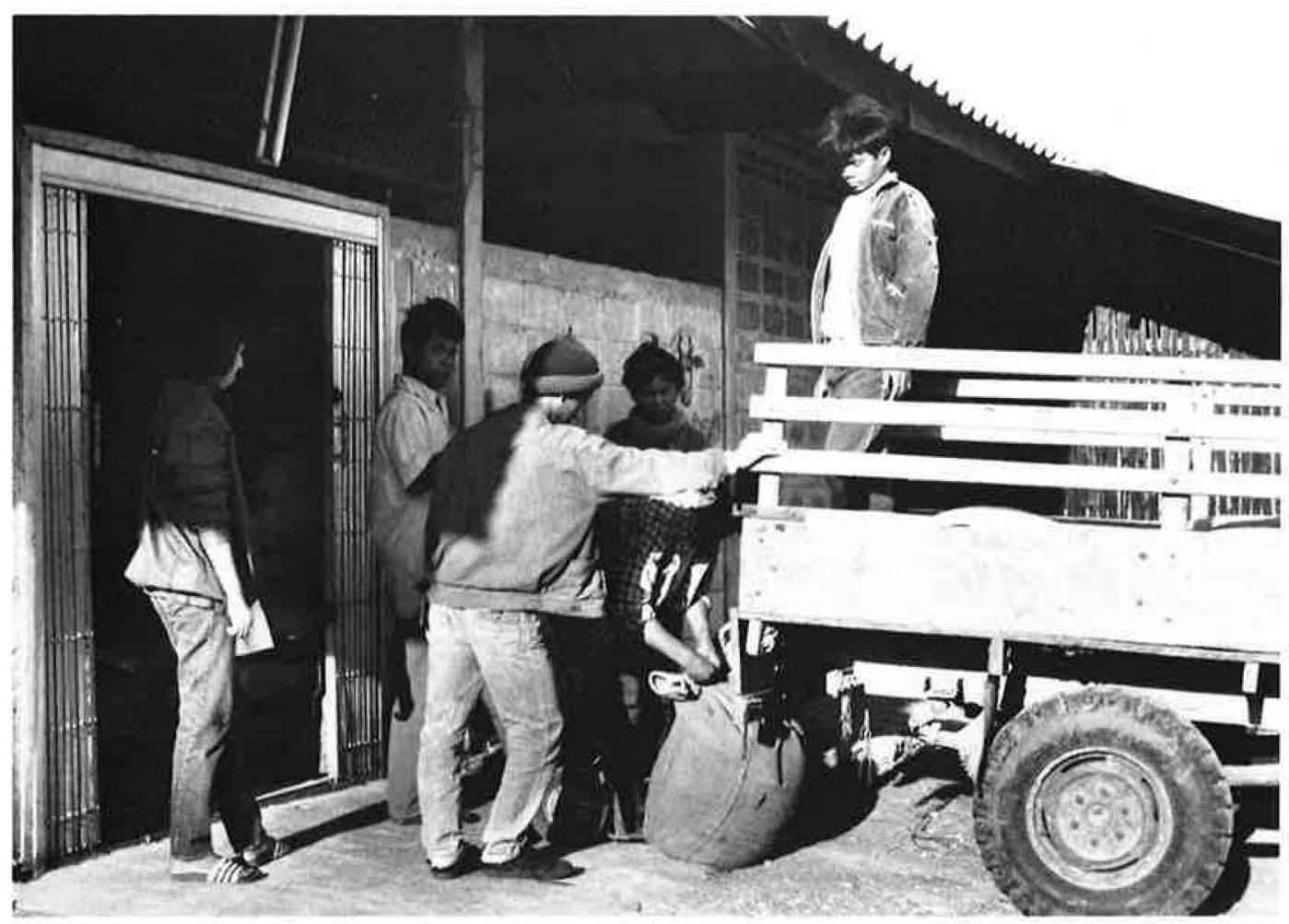



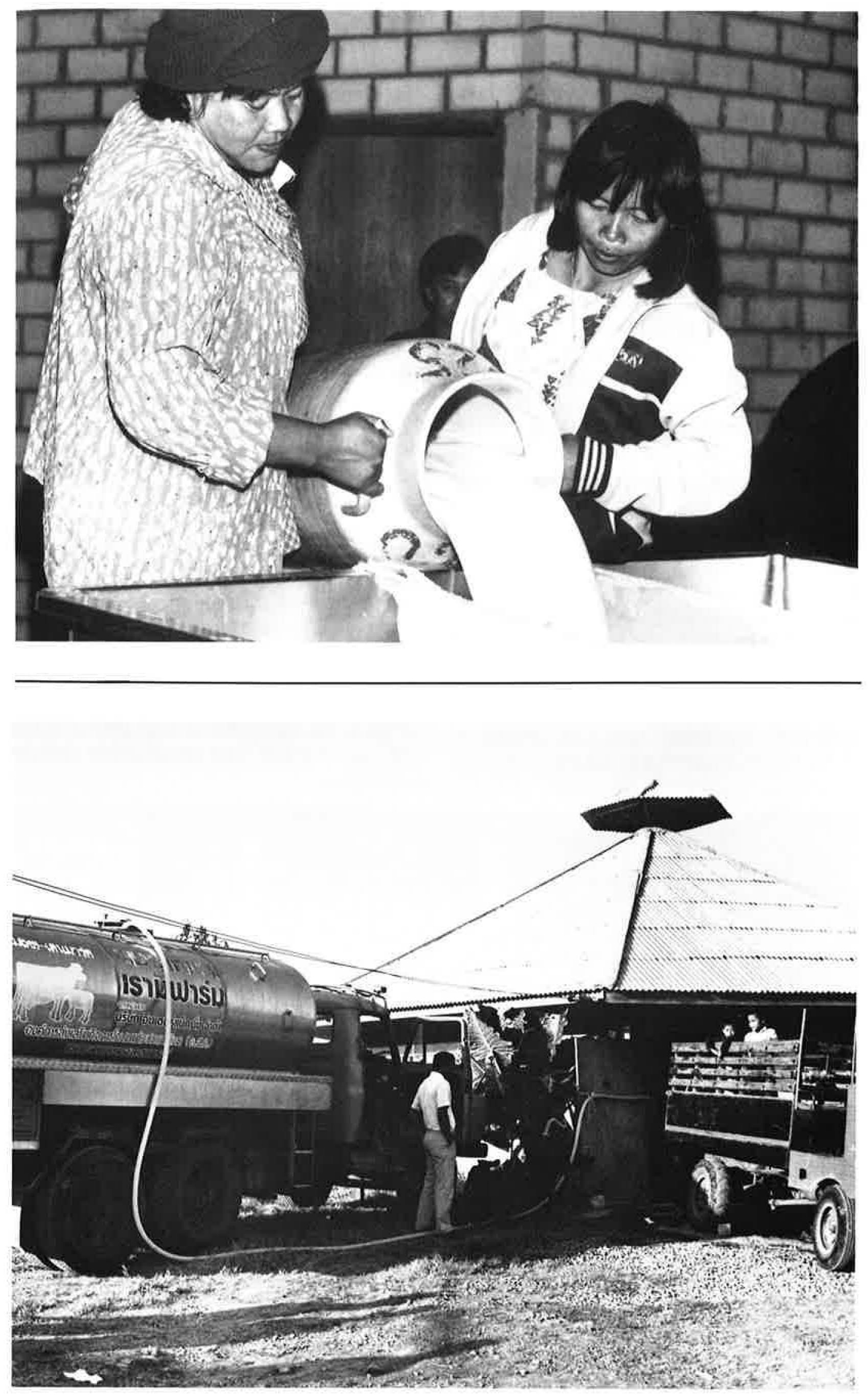
Later, SVITA was able to persuade the processing plant to set up a milk collection center in the heart of the Muek-Lek area and to establish twice daily pick ups in their refrigerated trucks. Now the women only have to hire transportation to take their milk to the collection center at a minimal cost of 100 to 300 bhat ( $\$ 4-\$ 12)$ per month, depending on the distance. SVITA also successfully lobbied the Rural Employment Generation Project, a public works scheme, to construct roads linking villages participating in the dairy project with the collection center and the milk processing plant.

\section{Project Results}

"Dairying provides a steady income that we can depend on," explains Lek. Somchit smiles in agreement. "We are no longer worried about being constantly in debt," she says. As a result of the project, women's workloads have increased by an average of two hours per day. Previously there were seasonal highs and lows, but now the work is spread out more evenly throughout the year. "But working hard is good," says Lek. "We have an increased income and we are proud."

\section{Improved Income}

Prior to joining the dairy project, many families in Muek-Lek were unable to escape a yearly cycle of debt. For families that became part of the dairy project, things have changed. The figures below indicate that Muek-Lek dairy farmers have doubled or tripled their farm income over a two to threeyear period.

In addition, many families continue to grow corn for the local market, even though women's participation in field agriculture has, in many cases, declined as a result of their involvement in dairying. Additional income is sometimes earned by family members who work as casual laborers, both skilled and unskilled. Sawon's husband, for example, occasionally finds work as a carpenter, earning 80 bhat $(\$ 3.20)$ per day; Lamoon makes 100 bhat $(\$ 4.00)$ every day, in addition to her dairy income, by selling homemade noodles in the village market.

How are families spending their extra income? For one thing, they are eating better. The variety of foods consumed has increased and the quality has improved. Instead of eating only preserved fish, for example, families can now afford fresh fish. And instead of eating only two meals a day, they can now eat three. Most families with schoolaged children also report spending more on their education. With her extra income, Chin sends her oldest son to school in Bangkok. Similarly, Noo is now able to send both her children to a government school in Saraburi.

Almost all the families in the dairy project have invested in more cattle. In the three years since the project started, the number of dairy cows has doubled. Some families also have used their dairy income to improve their farms, such as planting better quality grass in fields that otherwise would be left fallow. Many have made improvements on their houses; for example,

\begin{tabular}{llll}
\hline Activity & Income & Expenses & Net Income \\
Corn Farming & Bt. 30,720 & Bt. 20,224* & Bt. 10,498 \\
& $(\$ 1229)$ & $(\$ 809)$ & $(\$ 420)$ \\
Dairy Farming & Bt. 95,730 & Bt. 58,651** & Bt. 37,079 \\
2nd Year & $(\$ 3830)$ & $(\$ 2346)$ & $(\$ 1484)$ \\
Dairy Farming & Bt. 122,205 & Bt. 73,213*** & Bt. 48,992 \\
3rd Year & $(\$ 4888)$ & $(\$ 2928)$ & $(\$ 1960)$ \\
\hline
\end{tabular}

${ }^{*}$ Includes cost of seeds, plough and thresher rental

${ }^{* *}$ Includes bank repayment (30\% of monthly income), cost of veterinary services, feed, and transportation 
some have replaced bamboo walls with stronger wooden board and a few have even constructed concrete houses. Finally, several of the women have managed to pay off their entire loan.

\section{Increased Skills}

Niphaporn is a confident and articulate young mother of two. Her husband, who suffers from a severe nervous disorder, is confined to bed. Their children, a girl aged four and a boy aged two, live with her mother in Bangkok. Niphaporn sees them once a month when her mother comes to the village with medicines for her husband. Niphaporn's day starts at 4:00 a.m. when she turns on the electric power generator and rounds up the cows. In the cool season, the animals are washed with warm water prior to milking. In her experience, "if a cow has just given birth, it gives $22 \mathrm{~kg}$. of milk a day; but if it has been eight months or more since it has calved, it gives less than half that amount." By 7:00 a.m. the cows (she now owns 16) have been machine milked and are back out to pasture. Then, with the help of a hired hand, she cleans out their stalls. During the rainy season, after breakfast, she cuts the enriched grasses which she grows for feed. In the afternoon, the whole milking process is repeated. Today Niphaporn is earning more than 3000 bhat per month, after expenses, from dairying.

Women dairy farmers have expanded their traditional financial management responsibilities to include the family dairy enterprises in which they have a primary entrepreneurial stake. The women are also more involved in day-to-day operations and care of the animals than any other family member. It is usually the women who milk the cows, mix the feed, and call the veterinarian. Most of the women learned these skills through the government training course in animal husbandry. In addition, since the project began, the women have gained confidence in dealing effectively with government officials.

As yet, however, the women dairy farmers do not actively participate in the running of the feedmill cooperative. "As long as it's running all right, the women tend to let it be," says Dr. Malee of SVITA. "For example, they don't ask questions about how the money collected is used. But that may change over time," she adds.

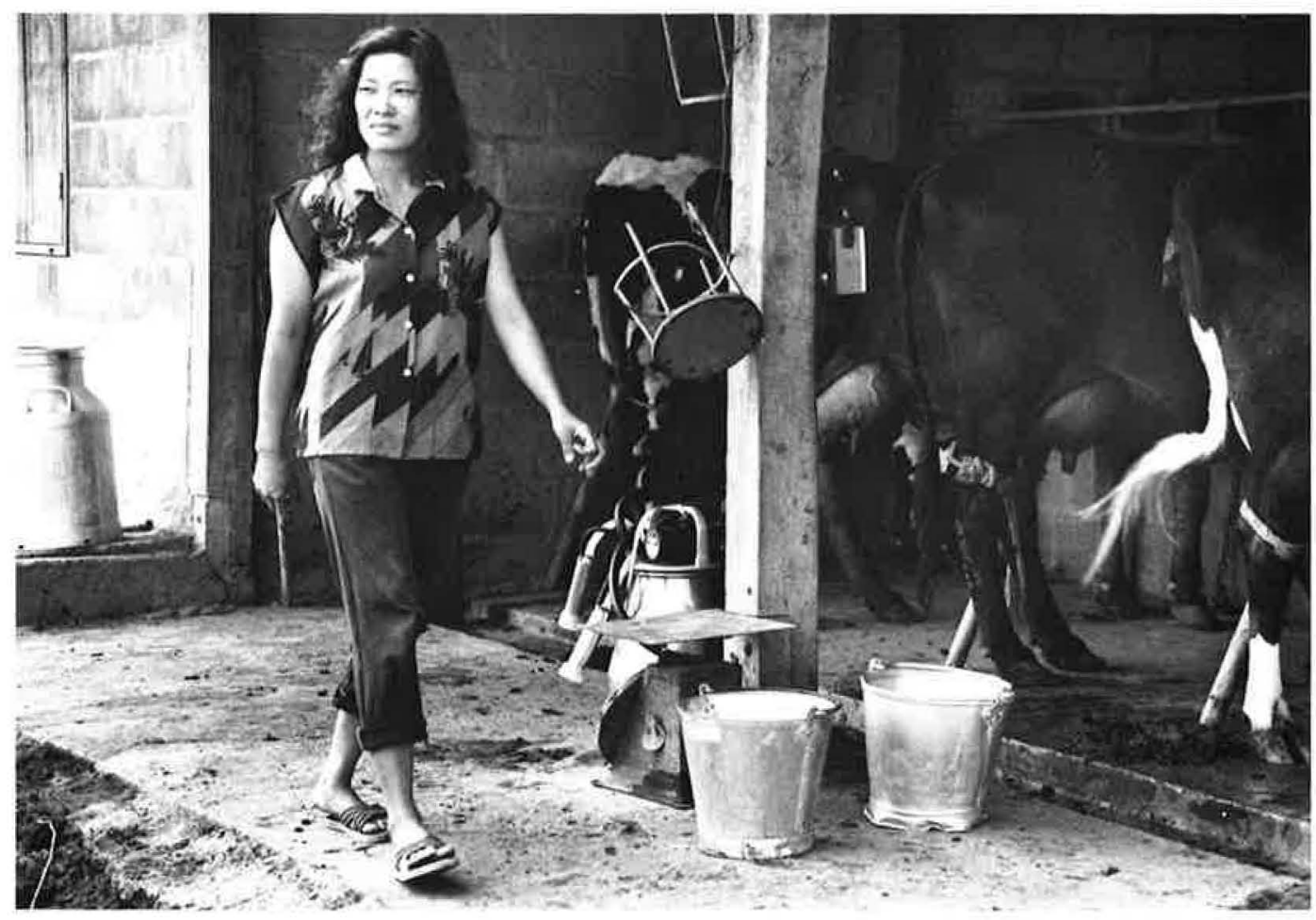



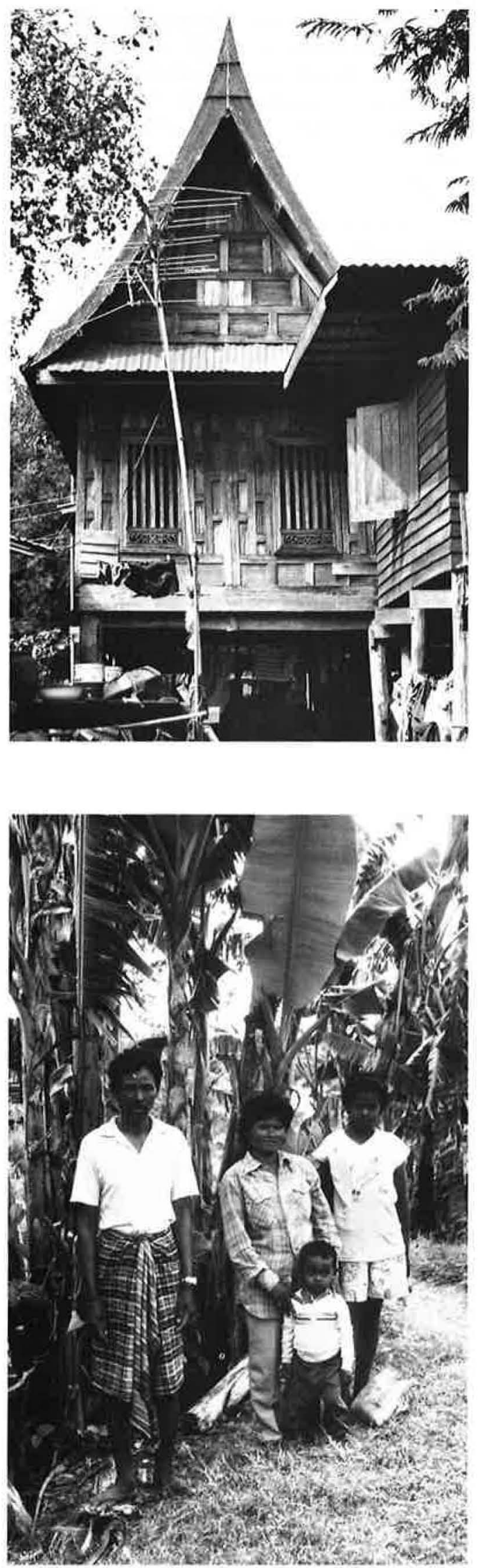

\section{Strengths and Weaknesses of the Muek-Lek Experience}

The role of outside catalysts in a project can be both a strength and a weakness. The sophisticated framework for providing credit and minimizing risk which permitted the successful establishment of the MuekLek Dairy Project is largely attributable to the crucial roles played by SVITA, the local land reform officer, and the Bangkok Bank. Their involvement was responsible for the sound planning that has characterized every phase of project implementation. The personal contacts and drive of Dr. Malee, Ms. Charungcharoenvej, and Khun Kamthorn were crucial in putting all the pieces together into a workable whole.

However, outside support must be used carefully so as not to undermine people's ability and willingness to learn how to control and manage income-earning activities on their own. Given the risk factors involved in dairying, the project sought to ensure that the financing, training, and technical and marketing aspects of the project would not have to be the direct responsibility of the participants. Rather, the intermediary agencies brought existing services within reach of the women farmers and, as much as possible, integrated project mechanisms into existing institutions so that they became a part of the standard operating procedures of these organizations. For example, loan repayment is directly handled by the processing plant which purchases the milk. It was designed to relieve the individual farmers of this responsibility.

When SVITA withdrew from the project in 1987, the Saraburi provincial administration took over its role as project facilitator. The day-to-day business of dairy farming and feedmill management was in the hands of the farm families. When senior government officials had to be contacted or outsiders tried to interfere with project operations, the farmers were able to call upon the land reform officer for help. While this project approach is not an example of a totally "participatory" approach, evident in other editions of SEEDS, it was successful in linking women with systems which could respond to their needscredit, technical services, training and marketing - without exposing them to the very real threat of failure. As a result, poor women 
achieved access to governmental support systems originally designed to serve the needs of large farmers. It has also provided a basis from which women can develop the skills needed to exert greater control over project management, now that they have experienced financial success and are firmly established as dairy farmers.

\section{Lessons Learned}

The Muek-Lek project is exemplary in that it captured a growing industry early to the benefit of women, before control by largescale interests had become entrenched. The project placed ownershp of significant productive resources, in this case dairy cows, squarely in the hands of women. Overall, it offered poor rural women an unusual opportunity to learn new skills in a highly lucrative, relatively young and growing sector of the mainstream agricultural economy.

1. Women can successfully become lead beneficiaries in a new industry when the venture is supported by proper re- search and planning, and provided with sufficient technical and financial support from the government and the financial community. Dairying in Thailand is a nontraditional activity for women, as well as men. The decision to make women the primary recipients of loans for the dairy project has insured their opportunity for leadership in this new field. This is particularly significant because in Thailand, as in most developing countries, key productive resources such as credit are generally unavailable to poor rural women.

2. The flexible division of labor between men and women in rural Thailand, and the relatively high level of underemployment common during the slack agricultural seasons, made it possible for the women to take on the added responsibility of dairy farming. Because family members were willing to shift work burdens and there was seasonal unemployment in the area, it was possible to introduce and carry out project activities. The men's willingness to take up more of the field agricultural activities, as the women became more involved in dairying, made it possible to handle the increase in farming chores.

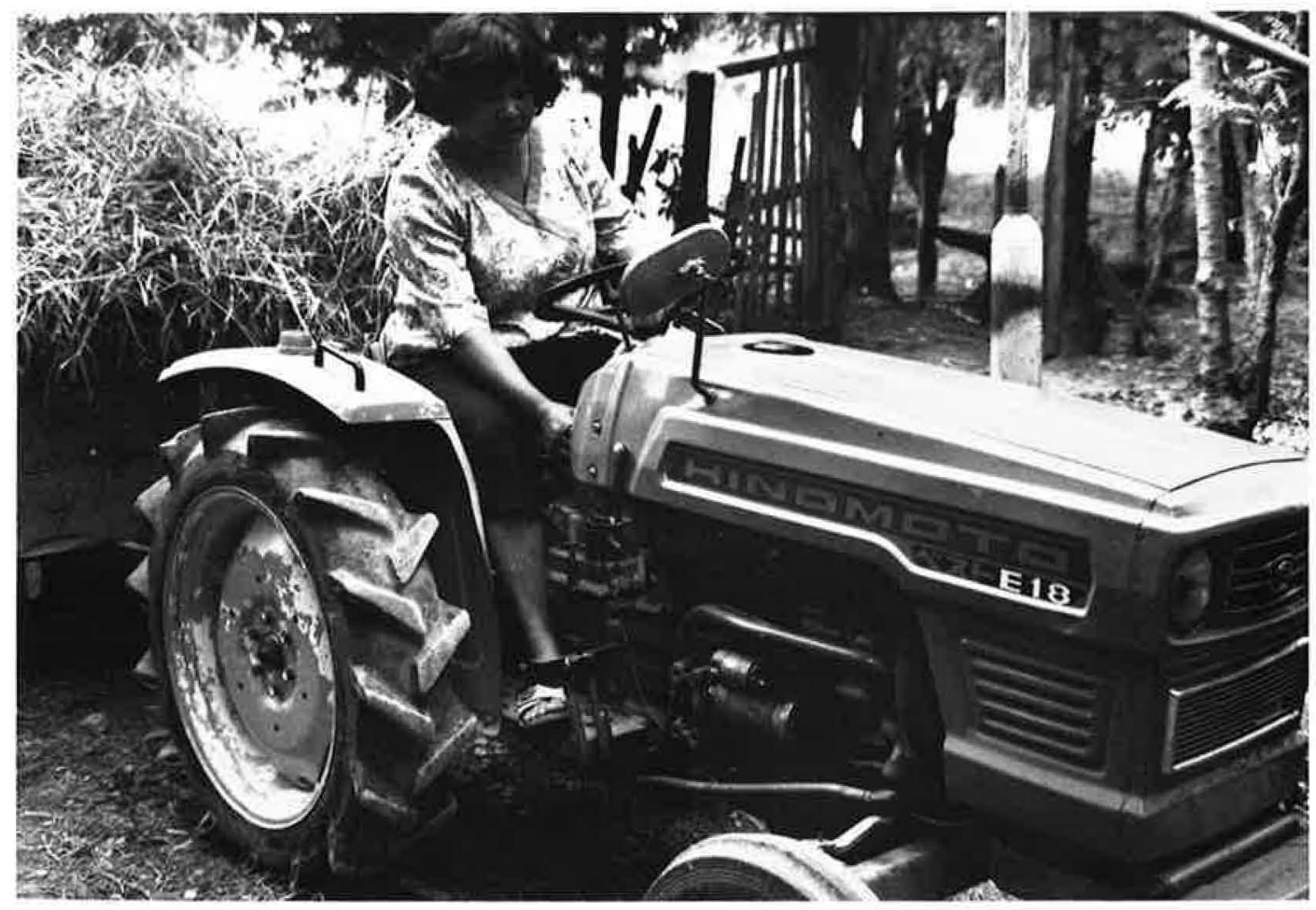


3. The minimum land requirement for keeping dairy cattle, 10 rai or 1.6 hectares, could be met by most families within the Muek-Lek land reform area. This ensured access to the project by the majority of the poorest women. In other parts of the world, many families own or control far less land.

4. A balance must be struck between potentially high risks and potentially high returns on investment. Prior to beginning dairy farming, the annual income of approximately 70 percent of Muek-Lek households was 10,000 bhat. The four-cow minimum required by the project meant that participating families must take out a loan of at least 158,000 bhat-an indebtedness fifteen times higher than their pre-project annual income. Fortunately, the success of the project resulted in a three-fold increase in incomes by the third year. Still, the level of indebtedness is a risk which warrants serious attention.

5. The risks of a high yield/high loss venture must be minimized through a systematic effort to bulid capacity and skills of participants and provide for insurance to compensate for potential losses. Incorporating appropriate training for farmers, access to veterinary care, and project-controlled access to high quality feed helped the project reduce the risk incurred through the importation of high yielding breeds which are generally more susceptible to local diseases. By providing the farmers training in animal husbandry and by assuring on-going provision of veterinary care, the project was able to avoid significant loss of livestock. It also was able to institute the first insurance coverage for livestock ever to be underwritten in Thailand. In addition, establishment of the feedmill cooperative, which is owned by the farmers, insures a continuous supply of high quality feed.

6. Establishing clear linkages to marketing channels was another key element in the success of the project. Prior to implementing the project, market links were firmly established with the milk processing plant, thus insuring a steady flow of income to participants. Quick and effective response to transportation problems, experienced early in the project, strengthened these linkages and, given the perishable nature of the product, prevented any loss being incurred by the farmers. Many income-generating projects for women in the Third World flounder for lack of an assured market for the products they produce.

The author wishes to thank Dr. Malee Suwana-adth and Khun Chinda Charungcharoenvejj for providing valuable information and for freely sharing their comments and insights. Also, the author gratefully acknowledges the assistance of Robert Retka who served as translator during field interviews. 


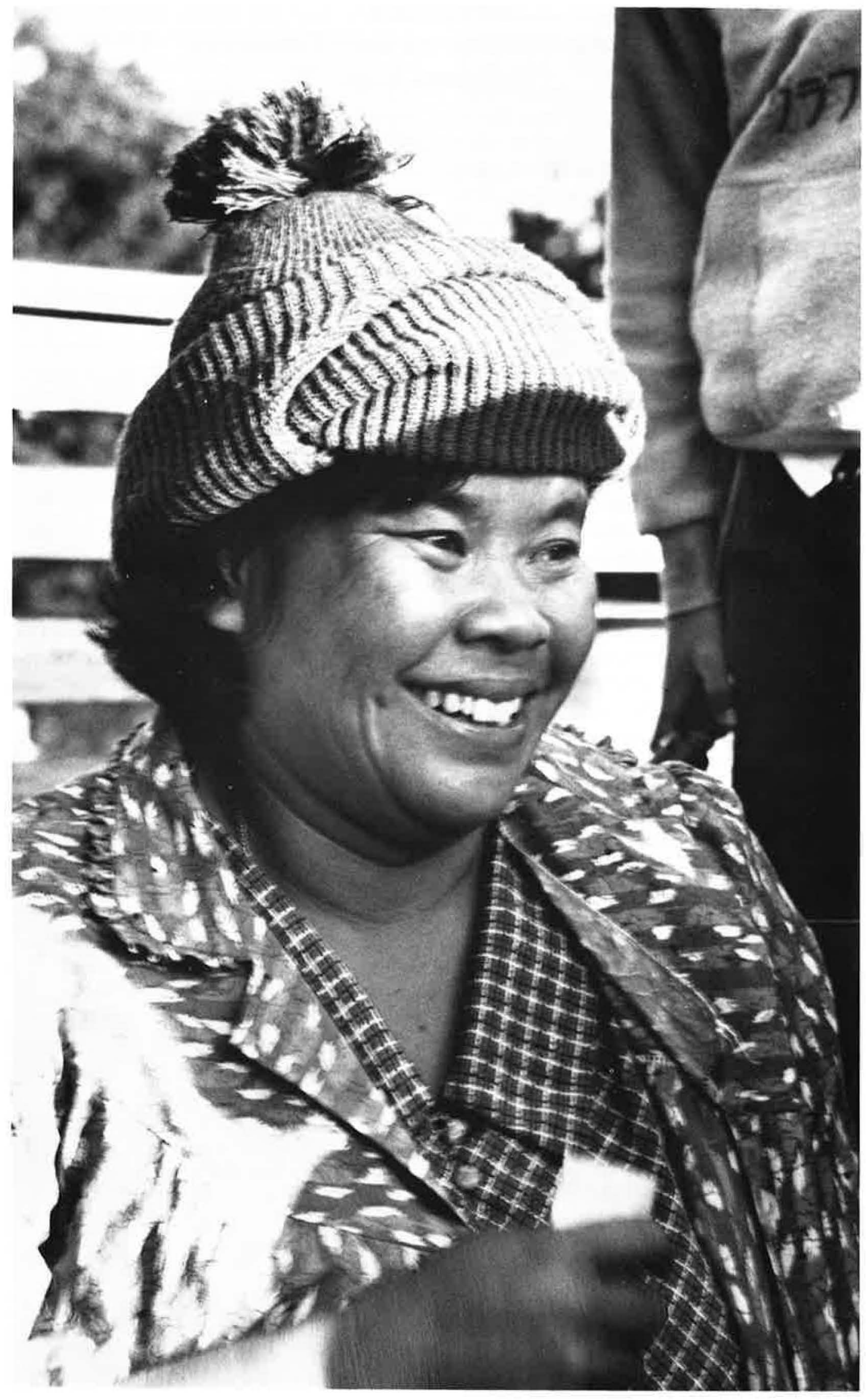




\section{APPENDIX \\ Women in Dairying: the India Experience \\ by Kalima Rose}

Unlike the experience in Thailand, dairying is a traditional occupation in rural India, performed largely by women in some 75 million households who daily feed, water, bathe and milk the family cattle. Dairying also provides wage and in-kind income for poor women who care for the cattle of large dairy producers and, for landless and marginal families, income derived from the sale of milk helps bridge gaps between seasonal agricultural labor.

In 1969, the National Dairy Development Board (NDDB) of India initiated a massive program called "Operation Flood" designed to expand marketing opportunities for the rural poor while, at the same time, creating a larger source of milk for urban areas through the establishment of village milk cooperatives. Built into the program was an extensive network to transport milk from village to processing centers to market, thus shifting much subsistence milk production to commercial production while, at the same time, insuring fair rates for producers. The program worked on a model of one to four cows per household and was considered "lowrisk," since rural families already owned cattle and knew how to care for them. Yet while it is women who actually care for the cattle, the program initially targeted men to join the village cooperatives and to occupy all the management positions from local to district to state level. The men, therefore, also collected the payments and managed the co-ops.

Women's entry into the NDDB movement began in 1978 when the Self-Employed Women's Association (SEWA) of Ahmedabad, in Gujarat State (also home of the NDDB), lobbied the Dairy Board to extend training to village women in the areas of animal husbandry, dairying, and cooperatives. The aim was to enable women to assume decision-making roles in the dairy movement while, at the same time, gaining some control over income earned. As a union of women who work in the informal sector in both rural and urban areas, SEWA was able to link assetless women with the nationalized banks to get loans to buy cattle, while the NDDB developed training materials for illiterate women and helped organize women's cooperatives. Although for the first four years they met resistance from vested interests and from men who were reluctant to allow women to control resources, the women's cooperatives eventually became stabilized, giving women their first economic and decision-making roles in the dairy sector.

In 1983, the Dairy Federation of the state of Andhra Pradesh and the Ford Foundation created a state-wide program targeting formation of women's cooperatives. Women extension staff were trained to organize the all-women co-ops, which now number 225 and include 16,000 women. Beginning in 1986, similar initiatives were begun on a large scale in Bihar, one of India's poorest states, where existing cooperatives had been plagued by corruption. There are now 125 co-ops in the state with 6000 women members.

By 1990, some 25,000 women had been organized as members of over 500 all-women cooperatives in India. Experience shows that women's cooperatives tend to be more stable than those controlled by men and they produce more milk than men's coops under similar conditions.

The most important elements for success of the cooperatives have been welldeveloped networks for delivery of training and support services. Some cooperatives have tapped the nationalized banks for loans and subsidies under the Integrated Rural Development Programme, while others have had greater success by creating their own revolving loan funds which are not subject to the delays, security demands, and inflexible payment schedules imposed by banks.

Due to women's previous exclusion not only from business and financial control, but also from access to basic literacy and numeracy skills needed to manage accounts, 
management by women has been an enormous challenge in rural areas and has required extensive training. Management and administration of women's dairy cooperatives is done completely by women, except in Andhra Pradesh, where 80 percent of the co-op secretaries are men.

In recent years, the NDDB has begun to solicit the active participation of women in the dairy movement and has appointed two women to each of its five-person teams of extension workers. However, NDDB is not promoting formation of all-women's cooperatives but rather participation of women in mixed co-ops. Many women-in-development activists still feel that all-women cooperatives are a better strategy: Mixed co-ops currently have only ten percent women members and, as women are generally conditioned to defer to men in public, mixed societies are less conducive to women taking control.
Some observers believe that the NDDB may come around to promotion of all-women cooperatives, but whether they do or not, all cooperatives still face the issue of self-sustainability. Outside donors to the state federations continue to support the costs of organizing women's cooperatives and the salaries of women extension workers. Once a cooperative is established and registered (two to three years), it becomes self-supporting, but women extension workers still continue to provide valuable support. However, even if the state programs were not to continue covering the cost of female extension workers in the future, the existing co-ops should be able to continue on their own.

While the examples noted above are all progressive steps that have been taken, more still needs to be done to acknowledge and promote women's roles in the Indian dairy industry.

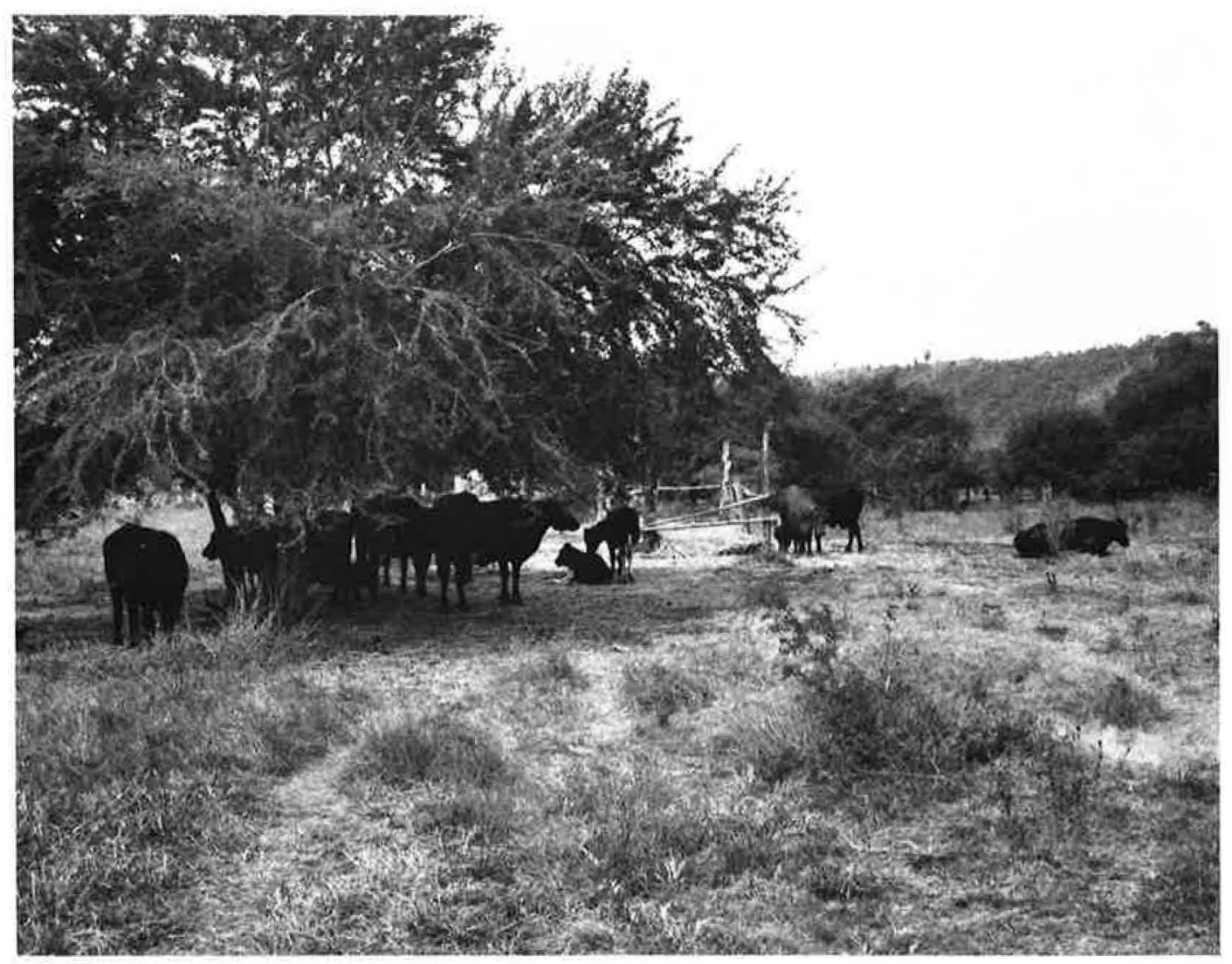




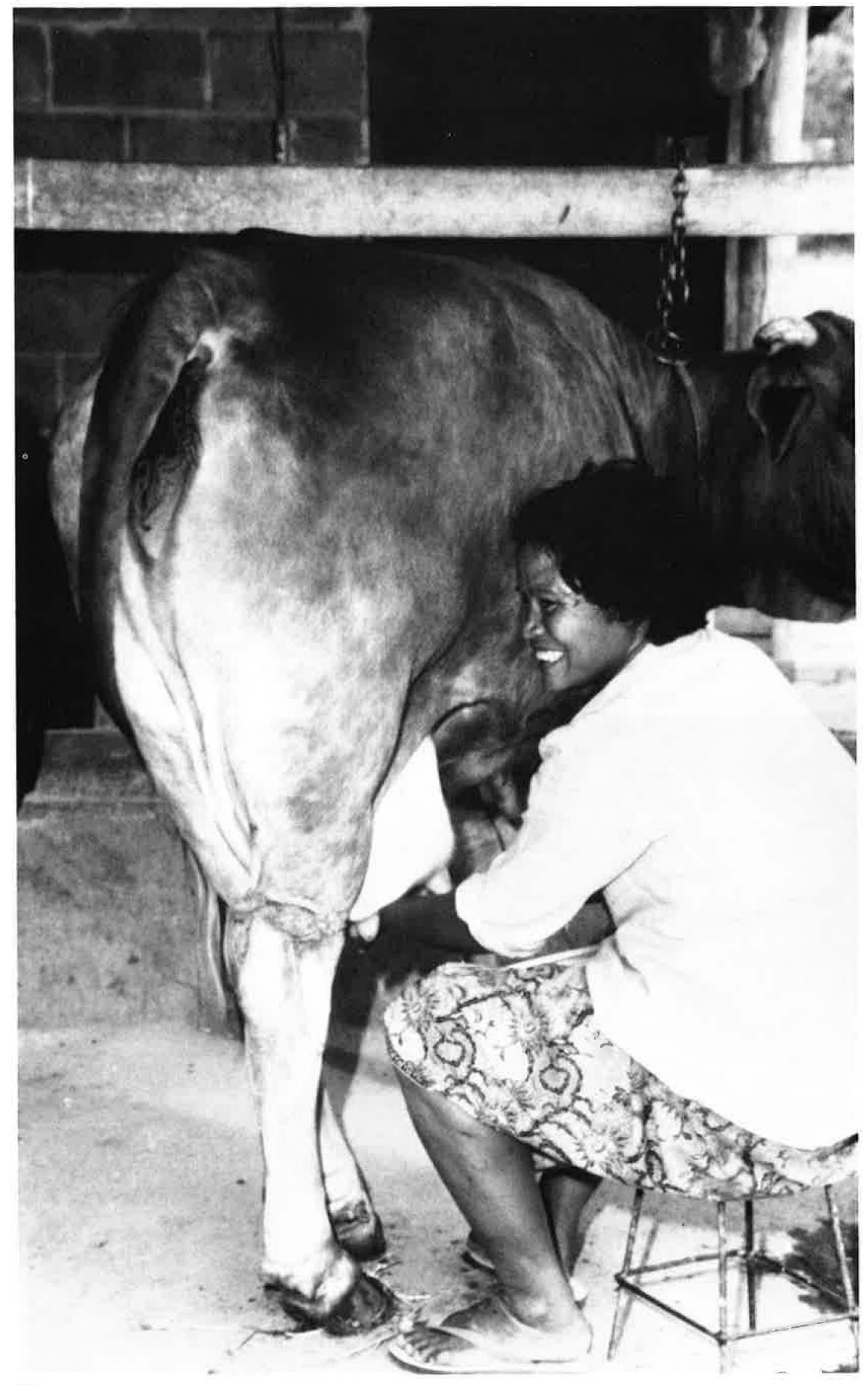


Design: Ann Leonard

Typography: Village Type and Graphics

Photos: Kim Retka

Printing: Graphic Impressions, Inc.

We invite your comments and your ideas for projects which might be included in future editions of SEEDS. If you would like additional copies of this issue or would like to be included on the SEEDS mailing list, please write to:

$$
\begin{gathered}
\text { Ann Leonard, Editor } \\
\text { SEEDS } \\
\text { P.O. Box } 3923
\end{gathered}
$$

Grand Central Station

New York, New York 10163 U.S.A. 


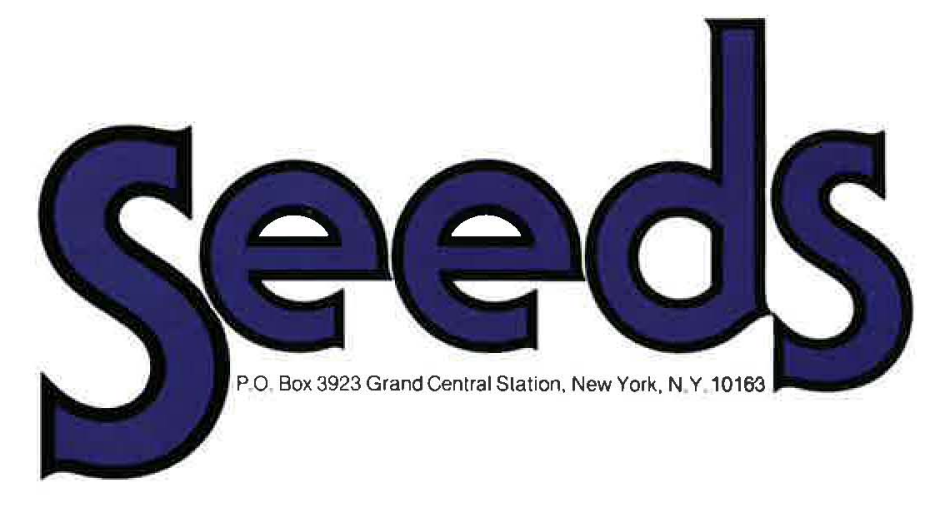

